J. Lake Sci. (湖泊科学), 2020, 32(6): 1771-1783

DOI 10. 18307/2020. 0617

(c) 2020 by Journal of Lake Sciences

\title{
以鲢、鳙养殖为主的长江中下游武山湖浮游植物群落结构特征”
}

\author{
张佳敏,高 健 ${ }^{* *}$,杨 诚, 张泽慧, 潘 超,廖明军,赵以军,王和云,杨雨慧 \\ (湖北工业大学河湖生态修复与藻类利用湖北省重点实验室,土木建筑与环境学院, 武汉 430068)
}

\begin{abstract}
摘 要: 武山湖是紧邻长江的通江型富营养化湖泊, 是国家级湿地公园. 为切实了解该湖在以鲢、鳙养殖为主的情况下浮 游植物结构特征, 于 2017 年 9 月- 2018 年 8 月对其浮游植物群落结构特征及水质开展了监测. 监测结果表明武山湖水质 全年处于轻度富营养到重度富营养水平之间; 12 次共采集浮游植物 7 门 100 种 (属), 浮游植物优势种共有 23 种,其中蓝 藻门有 9 种, 绿藻门有 8 种, 硅藻门和隐藻门各有 3 种. 夏季和秋季蓝藻门优势种最多且优势度高, 冬季和春季绿藻门和 硅藻门优势种多且优势度高. 武山湖浮游植物每月优势度最大的种类主要有蓝藻门微囊藻和细小平裂藻、绿藻门小球藻 以及硅藻门小环藻. 浮游植物生物量峰值出现在 6 月, 达 $34.77 \mathrm{mg} / \mathrm{L}$; 丰度峰值出现在 7 月, 达 $341.46 \times 10^{6} \mathrm{cell} / \mathrm{s} / \mathrm{L}$. 几余分 析 (RDA) 和线性相关分析均表明浮游植物丰度和生物量与总磷、温度和 $\mathrm{pH}$ 均呈显著正相关, 且蓝藻门生物量和丰度以 及优势属与总磷和温度均呈显著正相关. 研究结果表明武山湖浮游植物丰度和生物量在夏季均很高, 发生蓝藻水华的风 险较大. 相对于氮, 磷是更重要的限制浮游植物生长的营养元素.
\end{abstract}

关键词: 武山湖; 浮游植物; 群落结构; 鲢; 鲜

\section{Phytoplankton community structure of Lake Wushan stocked densely with planktivorous filter-feeding bighead and silver carp, middle and lower reaches of the Yangtze River*}

ZHANG Jiamin, GAO Jian ${ }^{* *}$, YANG Chen, ZHANG Zehui, PAN Chao, LIAO Mingjun, ZHAO Yijun, WANG Heyun \& YANG Yuhui

(Key Laboratory of Ecological Remediation of Lakes and Rivers and Algal Utilization of Hubei Province, School of Civil and Environment, Hubei University of Technology, Wuhan 430068, P.R.China)

Abstract: Lake Wushan is a highly eutrophic, shallow lake connected to the Yangtze River, and a national wetland park. In order to study phytoplankton structural characteristics in the lake stocked densely with silver carp (Hypophthalmichthys molitrix) and bighead carp (Aristichthys nobilis), we conducted a field survey on the phytoplankton community and lake trophic status from September 2017 to August 2018. Trophic status indices (TLI) showed the water quality was between mesotrophic and heavy eutrophic state. A total of 100 phytoplankton species (genera) belonging seven phyla were identified; twenty-three dominant species including nine species of Cyanophyta, eight species of Chlorophyta and both three species of Bacillariophyta and of Cryptophyta were observed. The dominant groups were Cyanophyta in summer and autumn, Chlorophyta and Cryptophyta in winter and spring. The phytoplankton size distribution had a trend biased toward miniaturization. Microcystis sp., Merismopedia tenuissima, Chlorella chlorophylla, Chlorella sp., and Cyclotella sp. were the predominant species in our 2017-2018 annual survey. The peak biomass appeared in June, reaching $34.77 \mathrm{mg} / \mathrm{L}$, and the peak abundance appeared in July, reaching $341.46 \times 10^{6}$ cells $/ \mathrm{L}$. Both of redundancy analyses and linear correlation analyses showed that total phosphorus, temperature and $\mathrm{pH}$ were positively correlated with phytoplankton abundance and biomass, and total phosphorus and temperature were also positively correlated with the biomass and abundance of Cyanophyta and the dominant genus. Our results showed that the abundance and biomass of phytoplankton were high, indicating high risks of cyanobacterial water blooms in summer months. Nitrogen was at least as important as phosphorus in limiting

* 2019-08-13 收稿; 2019-10-15 收修改稿.

国家自然科学基金项目(31500378,31670367)、国家重点基础研究项目(2016YFC0401702)、湖北省科技厅重大专 项 (2018ZYYD037) 和湖北工业大学高层次人才科研启动金项目 (337301) 联合资助.

** 通信作者; E-mail: jgao13@ hotmail.com. 
phytoplankton production in Wuhan lakes.

Keywords: Lake Wushan; phytoplankton; community structure; bighead carp; silver carp

武山湖地处湖北省武穴市北郊, 位于长江北岸, 距长江约 $4 \mathrm{~km}$, 属长江中游中型浅水通江湖泊. 1949 年, 武山湖水位 $16.0 \mathrm{~m}$ 时, 水面面积 $25.0 \mathrm{~km}^{2[1]}$, 现实测面积 $15.2 \mathrm{~km}^{2}$. 武山湖渔场属国营渔场, 专业养殖已 历时 60 余年. 20 世纪 80 年代初,武山湖水质清澈、水生高等植物多样性丰富,但自 1987 年以来其周围 6 家 工厂向其排污, 以及湖泊本身放养量逐渐增大, 再加上施肥和投旿养殖, 使湖泊水生生态系统日趋退化, 水 生高等植物种类相继消失, 全湖变为富营养化藻型生态系统 ${ }^{[2-3]}$, 其鱼类养殖品种逐渐变成以单一的鲢、鳙 为主. 近年来, 为贯彻落实国家和湖北省对长江大保护的重大决策部署, 针对武山湖水污染实施了一系列基 础建设工程, 对流域实施了控污、工厂搬迁和禁止施肥、投饵养殖等措施. 但由于控污不彻底 (表 1), 武山湖 水质长期处于富营养化水平, 水体主要超标因子为总磷、总氮以及高锰酸盐指数, 同时水体透明度低, 藻类 水华暴发的风险较大.

近年武山湖冬捕渔获量中鲢 (Hypophthalmichthys molitrix) 和鲜 (Aristichthys nobilis) 占 $90 \%$ 以上 (表 2), 由于鲢、鳙主要以浮游生物为食, 鲢、鳙养殖是否能够对武山湖浮游植物的过度增长或蓝藻水华的发生起到 控制作用备受湖泊管理部门关注. 鲢、鳙控藻技术即 “非经典生物操纵”已经广为研究者和湖泊管理部门熟 知 ${ }^{[4-6]}$, 但对鲢、鳙控藻问题在富营养化湖泊中的应用效果仍存在争议 ${ }^{[7]}$. 本研究基于对武山湖水体营养盐 浓度持续维持在较高水平和人湖河流污染仍然较高的认知前提下, 于 2017-2018 年对武山湖浮游植物群落 结构及其环境因子首次开展较系统的调查, 分析了武山湖浮游植物物种组成及对其产生影响的关键环境因 子. 研究假设以鲢、鳙养殖为主的武山湖浮游植物种群在滤食性鱼类牧食压力下其优势种主要为小型藻类, 但其密度和丰度仍将维持在较高水平. 本研究结果将为合理评估鲢、鳙放养在富营养湖泊中的控藻作用增 添原位资料。

\section{1 材料与方法}

\section{1 研究地点和采样时间}

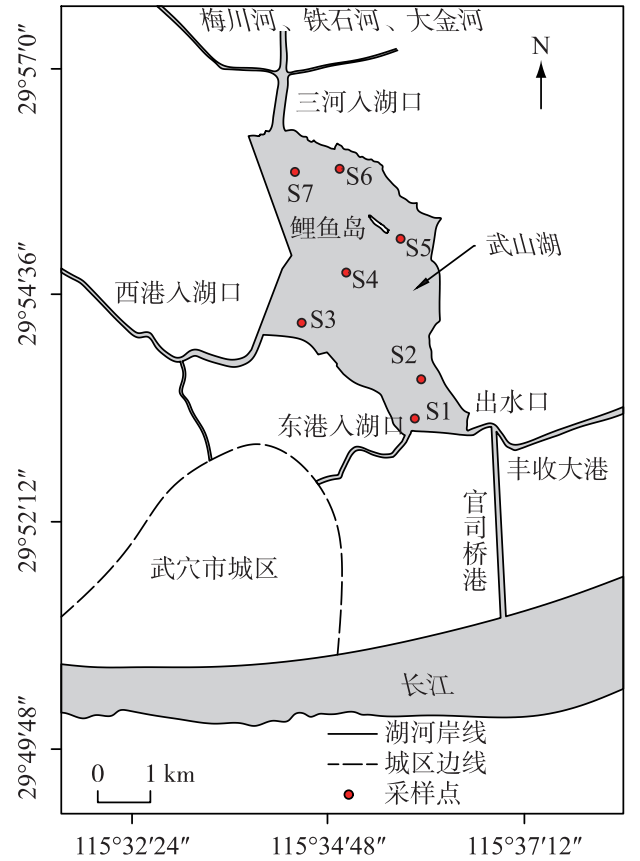

图 1 武山湖采样点位置

Fig.1 Location of sampling sites in Lake Wushan

武山湖 $\left(29^{\circ} 53^{\prime} 03^{\prime \prime} \sim 29^{\circ} 56^{\prime} 23^{\prime \prime} \mathrm{N}, 115^{\circ} 33^{\prime} 57^{\prime \prime} \sim 115^{\circ}\right.$ $36^{\prime} 40^{\prime \prime} \mathrm{E}$ ) 水域面积为 $15.2 \mathrm{~km}^{2}$, 常水位湖容约 $2690 \times 10^{4}$ $\mathrm{m}^{3}$, 最大水深为 $2.46 \mathrm{~m}$, 平均水深为 $1.27 \mathrm{~m}$. 武山湖位于 华阳水系源头, 人湖河流主要有三部分: 梅川河、大金河 和铁石河在近湖处 (即三河人湖口) 汇水, 城区东港来水 和西港来水. 武山湖出口在同一地方分叉,一是经丰收大 港连通太白湖, 经梅济港流人黄梅县龙感湖, 再经安徽省 华阳闸人长江; 二是经官司桥大港通过闸人长江(图 1).

采样时间为 2017 年 9 月 -2018 年 8 月, 水样及浮游 植物样品 1 个月采集 1 次. 武山湖 3 个主要人湖河口水 样 3 个月采集 1 次.

2017-2018 年对武山湖三大人湖河口水质监测的结 果表明 (表 1), 武山湖来水的氮、磷污染严重. 东港人湖 口在 2017 年 8 月、 11 月和 2018 年 2 月总氮 ( TN) 浓度均 大于 $10.0 \mathrm{mg} / \mathrm{L}$, 总磷 (TP) 浓度大于 $1.30 \mathrm{mg} / \mathrm{L}$. 西港人湖 口在 2017 年 8 月和 2018 年 2 月 $\mathrm{TN}$ 浓度大于 $10.0 \mathrm{mg} / \mathrm{L}$, $\mathrm{TP}$ 浓度大于 $0.80 \mathrm{mg} / \mathrm{L} .2018$ 年 2 月三河人湖口的氮、磷 污染最严重, TN 和 TP 浓度分别为 3.0 和 $0.30 \mathrm{mg} / \mathrm{L}$. 根据 查得的 3 个人湖河口的年均流量可计算 3 个人湖口汇人 武山湖的氮、磷总量, 其中东港一年排人武山湖的 TN 总 
量约为 $54.96 \mathrm{t}, \mathrm{TP}$ 约为 $5.79 \mathrm{t}$; 西港汇人的 $\mathrm{TN}$ 总量约为 $36.6 \mathrm{t}$, TP 约为 $3.09 \mathrm{t}$. 三河人湖口汇人氮、磷最多, $\mathrm{TN}$ 约为 $240.22 \mathrm{t}$, $\mathrm{TP}$ 约为 $32.11 \mathrm{t}$.

表 12017 年 8 月- 2018 年 5 月武山湖 3 个主要人湖河口不同季节的水质特征

Tab.1 Chemical characteristics of the three main estuary of Lake Wushan from August, 2017 to May, 2018

\begin{tabular}{|c|c|c|c|c|c|c|}
\hline \multirow{2}{*}{ 时间 } & \multicolumn{2}{|c|}{ 东港人湖口 } & \multicolumn{2}{|c|}{ 西港人湖口 } & \multicolumn{2}{|c|}{ 三河人湖口 } \\
\hline & $\mathrm{TN} /(\mathrm{mg} / \mathrm{L})$ & $\mathrm{TP} /(\mathrm{mg} / \mathrm{L})$ & $\mathrm{TN} /(\mathrm{mg} / \mathrm{L})$ & $\mathrm{TP} /(\mathrm{mg} / \mathrm{L})$ & $\mathrm{TN} /(\mathrm{mg} / \mathrm{L})$ & $\mathrm{TP} /(\mathrm{mg} / \mathrm{L})$ \\
\hline 2017 年 8 月 & 15.17 & 1.56 & 10.39 & 0.89 & 1.03 & 0.18 \\
\hline 2017 年 11 月 & 16.17 & 1.32 & 5.73 & 0.44 & 2.73 & 0.22 \\
\hline 2018 年 2 月 & 11.46 & 1.31 & 11.78 & 0.81 & 3.02 & 0.30 \\
\hline 2018 年 5 月 & 2.47 & 0.58 & 0.95 & 0.31 & 0.51 & 0.27 \\
\hline
\end{tabular}

武山湖养殖投放鱼苗主要是鳙和鲢 (表 2); 近四年渔获量约在 1300 2000 t/a, 其中鲢约占 20\%, 鳙约占 70\%（表 2)，其他鱼类包括鲤(Cyprinus carpio)、鳊( Parabramis pekinensis)、鲫( Carassius auratus)、青鱼( Mylopharyngodon piceus)、鲌( Culters)、草鱼(Ctenopharyngodon idella)、黄颡鱼 (Pelteobagrus fulvidraco)、鳑鲏( Rhodeus sinensis Gunther)、粲条(Hemicculter Leuciclus) 等.

表 2 武山湖 2014-2018 年鱼类捕捞量统计 *

Tab.2 Fish catch in Lake Wushan from 2014 to 2018

\begin{tabular}{|c|c|c|c|c|c|c|c|c|}
\hline \multirow[b]{2}{*}{ 鱼类 } & \multicolumn{2}{|c|}{ 2014-2015 年 } & \multicolumn{2}{|c|}{ 2015-2016 年 } & \multicolumn{2}{|c|}{ 2016-2017 年 } & \multicolumn{2}{|c|}{$2017-2018$ 年 } \\
\hline & $\begin{array}{l}\text { 年初投放 } \\
\text { 量及占比 }\end{array}$ & $\begin{array}{l}\text { 捕捞量 } \\
\text { 及占比 }\end{array}$ & $\begin{array}{l}\text { 年初投放 } \\
\text { 量及占比 }\end{array}$ & $\begin{array}{l}\text { 捕捞量 } \\
\text { 及占比 }\end{array}$ & $\begin{array}{l}\text { 年初投放 } \\
\text { 量及占比 }\end{array}$ & $\begin{array}{l}\text { 捕捞量 } \\
\text { 及占比 }\end{array}$ & $\begin{array}{l}\text { 年初投放 } \\
\text { 量及占比 }\end{array}$ & $\begin{array}{l}\text { 捕捞量 } \\
\text { 及占比 }\end{array}$ \\
\hline 鳙 & $\begin{array}{c}36.19 \\
(87.1 \%)\end{array}$ & $\begin{array}{c}132.35 \\
(64.6 \%)\end{array}$ & $\begin{array}{c}38.33 \\
(90.4 \%)\end{array}$ & $\begin{array}{c}139.92 \\
(73.2 \%)\end{array}$ & $\begin{array}{c}23.48 \\
(97.1 \%)\end{array}$ & $\begin{array}{c}125.55 \\
(74.5 \%)\end{array}$ & $\begin{array}{c}20.84 \\
(94.7 \%)\end{array}$ & $\begin{array}{c}90.89 \\
(66.7 \%)\end{array}$ \\
\hline 鲢 & $\begin{array}{c}5.35 \\
(12.9 \%)\end{array}$ & $\begin{array}{c}58.01 \\
(28.3 \%)\end{array}$ & $\begin{array}{c}4.09 \\
(9.6 \%)\end{array}$ & $\begin{array}{c}30.64 \\
(16.0 \%)\end{array}$ & $\begin{array}{c}0.69 \\
(2.9 \%)\end{array}$ & $\begin{array}{c}26.51 \\
(15.7 \%)\end{array}$ & $\begin{array}{c}1.16 \\
(5.3 \%)\end{array}$ & $\begin{array}{c}33.95 \\
(24.9 \%)\end{array}$ \\
\hline 其他 & - & $\begin{array}{c}14.53 \\
(7.1 \%)\end{array}$ & - & $\begin{array}{c}20.65 \\
(10.8 \%)\end{array}$ & - & $\begin{array}{c}16.45 \\
(9.8 \%)\end{array}$ & - & $\begin{array}{l}11.49 \\
(4 \%)\end{array}$ \\
\hline 总量 & - & 204.90 & - & 191.21 & - & 168.50 & - & 136.32 \\
\hline
\end{tabular}

* 投放鳙鱼苗约 $0.25 \sim 0.5 \mathrm{~kg} /$ 尾, 鲢鱼苗约 $0.1 \sim 0.15 \mathrm{~kg} /$ 尾. 投放量和捕拹量的单位均为万 $\mathrm{kg}$; 数据来源于武山湖武黄渔 场. “一”表明无详细统计数据.

\section{2 样本采集及分析}

透明度 $(\mathrm{SD})$ 采用塞氏盘 (Secchi-disk) 现场测定. 水温 (WT)、pH 值和溶解氧 ( DO ) 等参数采用 YSI ProPlus 多参仪 (美国) 现场测定.

用 $5 \mathrm{~L}$ 有机玻璃采水器采集水表面下 $0.5 \mathrm{~m}$ 处水样,共计 $20 \mathrm{~L}$ 水样放置在用湖水洗净的塑料桶内,混合 后取约 $2.5 \mathrm{~L}$ 水样低温保存, 带回实验室分析水质. TN、TP 和高锰酸盐指数 $\left(\mathrm{COD}_{\mathrm{Mn}}\right)$ 等水质指标的检验方法 依据《水和废水监测分析方法 (第四版) $\rangle^{[8]}$.

取上述混合水样 $1 \mathrm{~L}$ 置于广口塑料瓶中用于浮游植物定量分析, 现场加人约水样体积 $1 \%$ 的鲁哥试剂固 定, 带回实验室静置沉淀 $24 \mathrm{~h}$ 以上后浓缩并在尼康倒置显微镜下计数, 浮游植物鉴定参照《中国淡水藻 类一一系统, 分类及生态 $\rangle^{[9]}$ 尽量鉴定到种, 其中部分硅藻鉴定到属. 计数方法为目镜视野法, 用 $0.1 \mathrm{~mL}$ 浮 游植物计数框在 $10 \times 40$ 倍光学显微镜下进行, 一般计数 50 个视野, 使所得到的细胞数在 300 以上, 每个样 品至少计数 2 片, 对量小而个体大的种类在 $10 \times 10$ 倍下全片计数. 根据浓缩倍数换算为每升水样中的细胞 数 ( cells $/ \mathrm{L})$, 即浮游植物的丰度. 由于浮游植物的比重接近 1 , 故可以直接由浮游植物的体积换算为生物量 (鲜重), 即生物量为浮游植物的丰度乘以各自的平均体积 ${ }^{[10]}$, 单位为 $\mathrm{mg} / \mathrm{L}$. 


\section{3 数据处理及分析}

1.3.1 综合营养状态指数评价 参考湖泊富营养化评价方法及分级标准 ${ }^{[1]]}$, 依据 Chl. $a$ 、TP、TN、SD 和 $\mathrm{COD}_{\mathrm{Mn}}$ 监测结果, 运用综合营养状态指数法对武山湖生态系统健康状况进行评价. 综合营养状态指数计算公式 如下:

$$
T L I(\Sigma)=\Sigma W_{j} \cdot T L I(j)
$$

式中, $T L I\left(\sum\right)$ 表示综合营养状态指数; $T L I(j)$ 代表第 $j$ 种参数的营养状态参数; $W_{j}$ 为第 $j$ 种参数的营养状态 指数的相关权重, 详细计算公式见参考文献 ${ }^{[11]}$.

参考《中国水资源公报》 ${ }^{[12]}$ 中湖泊、水库富营养化评分与分类标准将湖泊营养状态分成 5 级, 同一营养 状态下, 指数值越高, 其营养程度越严重: 贫营养 $T L I(\Sigma)<30$, 中营养 $30 \leqslant T L I(\Sigma) \leqslant 50$, 轻度富营养 $50<$ $T L I(\Sigma) \leqslant 60$, 中度富营养 $60<T L I(\Sigma) \leqslant 70$, 重度富营养 $T L I(\Sigma)>70$.

1.3.2 优势种 浮游植物优势种根据种的 Mcnaughton 优势度指数 $(Y)$ 来确定 ${ }^{[13]}$ :

$$
Y=\frac{n_{i}}{N} f_{i}
$$

式中, $n_{i}$ 为第 $i$ 种的个体数; $N$ 为所有种类总个体数; $f_{i}$ 为出现频率; $Y$ 值 $>0.02$ 的种类视为优势种. 优势种的 变化在一定程度上可直接反映水体污染程度和环境条件的改变 ${ }^{[1-15]}$.

1.3.3 统计分析 浮游植物丰度和生物量与 TN 、 TP、WT、DO 、 $\mathrm{pH} 、 \mathrm{SD}$ 和 TLI 指数的 Pearson 相关性分析用 SPSS Statistics 22.0 软件进行. 所有数据分析前首先进行正态分布检验, 不符合正态分布的数据用 $\ln (x)$ 处理 后分析.

穴余分析通过 CANOCO 4.5 进行, 在分析前, 先对物种丰度矩阵进行 DCA 去趋势分析, 用于排序的浮游 植物物种满足以下 3 个条件: (1) $Y \geqslant 0.02$ 的优势属; (2) 该物种在不同采样点的不同时期出现频率 $>12.5 \%$; (3) 该物种至少在 1 个采样点的相对密度 $\geqslant 1 \%$. 对篮选后的武山湖浮游植物物种进行 DCA 分析, 本研究中 最大轴小于 3 , 因此采用穴余分析 (RDA) ${ }^{[16]}$ 探讨武山湖浮游植物丰度与环境因子(包括 WT、DO、 $\mathrm{pH} 、 \mathrm{TN} 、 \mathrm{TP}$ 和 $\mathrm{SD}$, 而 $\mathrm{COD}_{\mathrm{Mn}}$ 值受浮游植物浓度的影响而被排除在外) 的关系. 为了获得数据正态分布, 将浮游植物和环 境因子 (除 $\mathrm{pH}$ ) 均进行 $\ln (x+1)$ 转换. 物种及环境因子选取 12 个月 7 个采样点共 84 个数据进行 RDA 分析. 在线性排序图, 从样方的点在物种箭头及其延长线的投影点可以表示它们之间的关系. 由样方到物种箭头 线的垂点可以判断样方物种的多度值, 垂点在物种箭头方向越远位置代表其物种多度越高, 反之越低 ${ }^{[16]}$.

聚类分析利用大型多元统计软件 PRIMER 5.0 进行, 对武山湖浮游植物优势种分别进行时间和空间的 聚类分析.

\section{2 结果与分析}

\section{1 武山湖水体理化特征和季节变化规律}

采样期间, 武山湖 WT 范围在 $7.8 \sim 34^{\circ} \mathrm{C}$. 水体 DO 浓度均值在 $5.57 \sim 15.03 \mathrm{mg} / \mathrm{L}$, 其中 $2 、 3$ 月各采样点 DO 波动较大. 水体 $\mathrm{pH}$ 值的范围在 7.41 9.12 之间, 其中 $2 、 3$ 和 5 月各采样点 $\mathrm{pH}$ 波动较大. 武山湖水体 $\mathrm{SD}$ 12 月最高, 均值为 $132.7 \mathrm{~cm}$; 而在 4 月最低, 均值为 $27.7 \mathrm{~cm}$, 其中有 8 个月的 $\mathrm{SD}$ 在 $40 \mathrm{~cm}$ 以下, 水体除 12 月 外均浑浊 (图 2).

武山湖 TP 浓度均值范围为 $0.17 \sim 1.05 \mathrm{mg} / \mathrm{L}$, 其值冬季低、夏季高, 最低值在 12 月, 最高值在 8 月. TN 浓度均值变化范围在 $1.34 \sim 3.14 \mathrm{mg} / \mathrm{L}$ 之间, 其值冬季高、夏季低, 最低值在 9 月, 最高值在 2 月, 与 $\mathrm{TP}$ 季节 变化相反; 尽管 2 月 TN 均值最高, 但各采样点浓度有明显差异, 其中 $\mathrm{S} 6$ 最高 ( $4.51 \mathrm{mg} / \mathrm{L}$ ), S2 最低 ( 2.09 $\mathrm{mg} / \mathrm{L}$ ). 武山湖 $\mathrm{COD}_{\mathrm{Mn}} 12$ 月最低, 均值为 $4.44 \mathrm{mg} / \mathrm{L}$, 而 2 月最高, 均值为 $8.88 \mathrm{mg} / \mathrm{L}$. 武山湖不同采样点 $\mathrm{Chl} . a$ 浓度差别很大, 12 月值最低, 平均 $6.22 \mu \mathrm{g} / \mathrm{L} ; 7$ 月 Chl. $a$ 浓度最高, 达 $125.08 \mu \mathrm{g} / \mathrm{L}$ (图 2). 武山湖富营养指数 $T L I$ 均值变化范围在 51.09 73.1 之间, 全湖全年处于轻度富营养到重度富营养水平, 其中 12 月和 1 月处于 轻度富营养, 7 月、 8 月和 11 月为重度富营养化,其他月份为中度富营养化.

\section{2 武山湖浮游植物特征}

2.2.1 浮游植物种类组成及优势种 采样期间武山湖共鉴定出浮游植物 100 种 (属), 隶属于 7 门 62 属. 其 

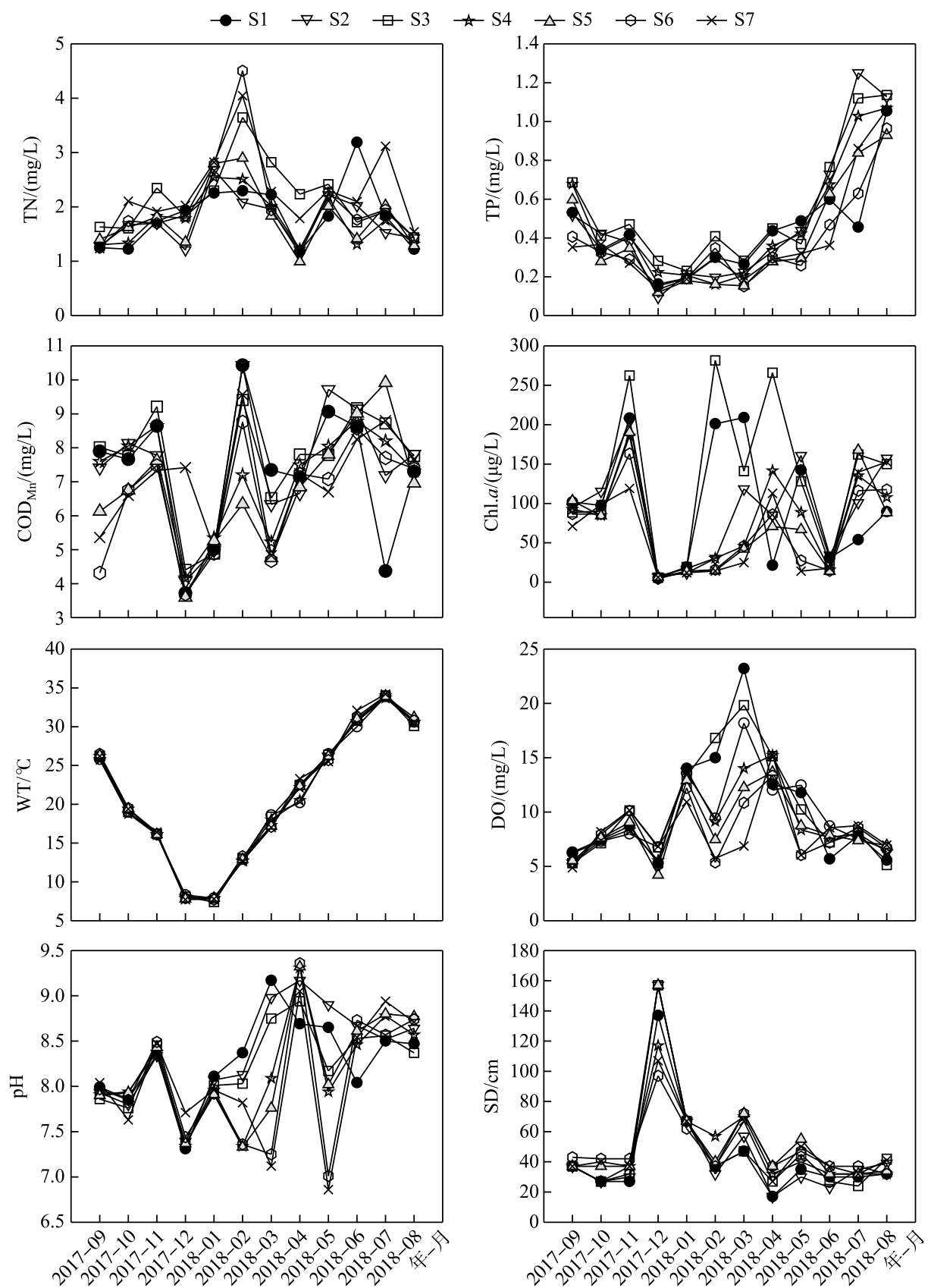

图 2 武山湖水体理化指标的时空变化

Fig.2 Spatial-temporal change of physicochemical parameters in Lake Wushan

中绿藻门种类数最多, 有 28 属 50 种, 占总种数的 $50 \%$. 硅藻门其次, 有 11 属 19 种, 占总数的 $19 \%$. 蓝藻门 有 10 属 14 种, 甲藻门和隐藻门分别有 4 属 5 种和 3 属 6 种, 裸藻门和金藻门最少, 分别有 4 属 4 种和 2 属 2 种.

浮游植物优势种共有 23 种, 其中蓝藻门有 9 种, 绿藻门有 8 种, 硅藻门和隐藻门各有 3 种. 其中绿藻门 的四尾栅藻 (Scenedesmus quadricauda) 在 12 次调查中作为优势种出现了 11 次, 硅藻门的小环藻属一种 $(C y-$ 
clotella sp.) 出现了 9 次, 蓝藻门的伪鱼腥藻属一种 (Pseudanabaena sp.) 与细小平裂藻 (Merismopedia tenuissi$m a)$ 均出现 7 次. 夏季和秋季蓝藻门优势种最多且优势度高, 秋季和春季绿藻门和硅藻门优势种多且优势度 高, 隐藻门的种类仅在 2018 年 1-3 月为优势种. 从秋季、冬季、春季到夏季, 武山湖最优势种的演替过程为 细小平裂藻、小环藻一种 (Cyclotella sp. ) 、小球藻一种 (Chlorella sp.) 再到微囊藻一种 (Microcystis sp.)、细小 平裂藻 $($ 表 3 ).

以武山湖浮游植物优势种群的丰度进行时间聚类分析 (图 3a), 在相似水平 47\% 时,2018 年 1 月和其他 月份分为两类; 在相似水平 $63 \%$ 时, 2018 年 1 月为一类, 2018 年 2-4 月和 2017 年 12 月为一类, 2017 年 911 月和 2018 年 5-8 月为一类. 以武山湖浮游植物优势种群的丰度进行空间聚类分析 (图 $3 \mathrm{~b}$ ), 结果表明 7 个采样点相似度很高, 在相似水平为 $93.5 \%$ 时仅分为两大类,一类为 $\mathrm{S} 1 、 \mathrm{~S} 2$ 和 $\mathrm{S} 3$, 一类为 $\mathrm{S} 4 、 \mathrm{~S} 5 、 \mathrm{~S} 6$ 和 $\mathrm{S} 7$.
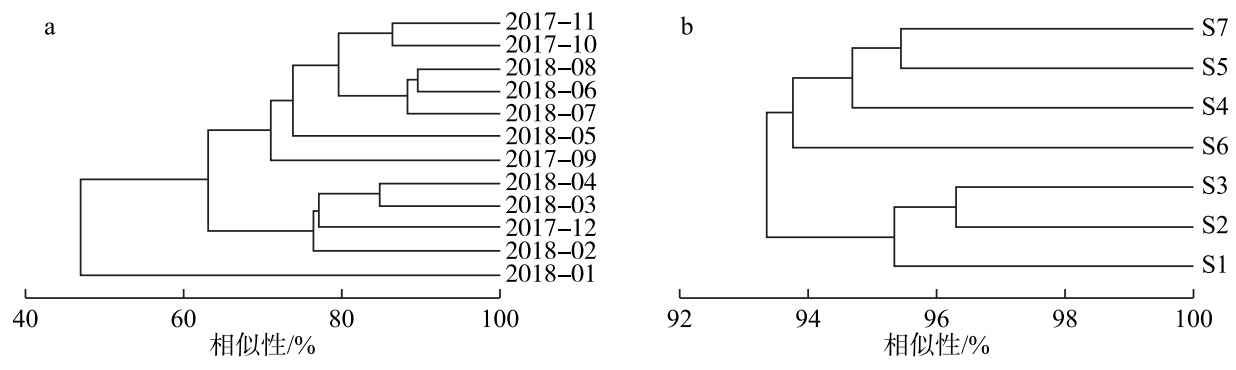

图 3 武山湖浮游植物优势种丰度的时间 ( a ) 和空间 (b) 聚类分析

Fig.3 Temporal(a) and spatial(b) cluster analysis of phytoplankton dominant species in Lake Wushan

2.2 .2 浮游植物丰度和生物量 武山湖采样期间各采样点浮游植物丰度在 $0.41 \times 10^{6} \sim 341.46 \times 10^{6} \mathrm{cells} / \mathrm{L}$ 之 间, 其中 2017 年 12 月全湖浮游植物平均丰度最低, 为 $1.10 \times 10^{6}$ cells $/ \mathrm{L} ; 2018$ 年 7 月浮游植物平均丰度最 高, 为 $230.10 \times 10^{6} \mathrm{cells} / \mathrm{L}$. 在 5-11 月, 蓝藻门的丰度占比最高, 占总丰度的 $65.14 \% \sim 88.76 \%$. 绿藻门的丰度 在 2017 年 12 月、2018 年 1 月和 4 月较高, 其中 2018 年 1 月浮游植物丰度突然增加, 尤其是绿藻门丰度达 $100.11 \times 10^{6} \mathrm{cells} / \mathrm{L}$, 占总丰度的 $93.01 \% .2018$ 年 2 月, 浮游植物优势种逐渐从绿藻门演替成硅藻门, 其丰度 $\left(15.72 \times 10^{6} \mathrm{cells} / \mathrm{L}\right)$ 占浮游植物总丰度的 $75.17 \%$. 硅藻门丰度在 2017 年 12 月和 2018 年 $3-4$ 月也比较高, 分别占总丰度的 $37.68 \% 、 35.03 \%$ 和 $30.49 \%$. 隐藻门只在 2018 年 3 月丰度比较高, 为 $6.08 \times 10^{6}$ cells $/ \mathrm{L}$, 占总 丰度的 $20.14 \%$. 其他门的浮游植物丰度均很低( 图 4).

武山湖采样期间浮游植物生物量在 $0.061 \sim 34.77 \mathrm{mg} / \mathrm{L}$ 之间, 其中 12 月浮游植物生物量最低, 6 月浮游 植物生物量最高. 7 月蓝藻门的生物量达 $4.83 \mathrm{mg} / \mathrm{L}$, 占比最多 $(32.55 \%) .11$ 月硅藻门生物量最高, 达 10.71 $\mathrm{mg} / \mathrm{L}$, 全年有 9 个月硅藻门生物量占总生物量的比例最高(图 4). 绿藻门 1 月生物量占比最多(达 $35.46 \%$ ), 而在 6 月份生物量最高 $(3.49 \mathrm{mg} / \mathrm{L})$. 隐藻门生物量 3 月最高 $(3.26 \mathrm{mg} / \mathrm{L})$, 裸藻门生物量最高出现在 6 月 ( $2.73 \mathrm{mg} / \mathrm{L})$ ( 图 4).

从丰度数据来看, 夏、秋季蓝藻门占优, 冬、春季以硅藻和绿藻为主; 从生物量数据来看, 春、秋、冬硅藻 门占优,夏季硅藻、蓝藻和绿藻均较高 (图 4).

\section{3 武山湖浮游植物与环境因子的关系}

Pearson 相关性分析结果 (表 4) 表明, TP 浓度分别与浮游植物丰度和生物量、蓝藻门丰度、绿藻门生物 量呈显著正相关, 与蓝藻门生物量呈极显著正相关. 水温与蓝藻门的生物量呈极显著正相关, 与浮游植物总 丰度、总生物量以及绿藻门生物量呈显著正相关. $\mathrm{pH}$ 与浮游植物总丰度、总生物量及绿藻门和硅藻门的丰 度、生物量均呈极显著正相关. 透明度与浮游植物总丰度和总生物量、硅藻门的丰度和生物量呈极显著负相 关, 与绿藻门生物量显著负相关. 除绿藻门丰度外, 浮游植物及其主要类群丰度和生物量均与综合营养状态 指数 $T L I$ 呈显著或极显著正相关. 蓝藻丰度与 DO 浓度呈显著负相关, 浮游植物及其类群丰度和生物量与 $\mathrm{TN}$ 浓度均不相关. 


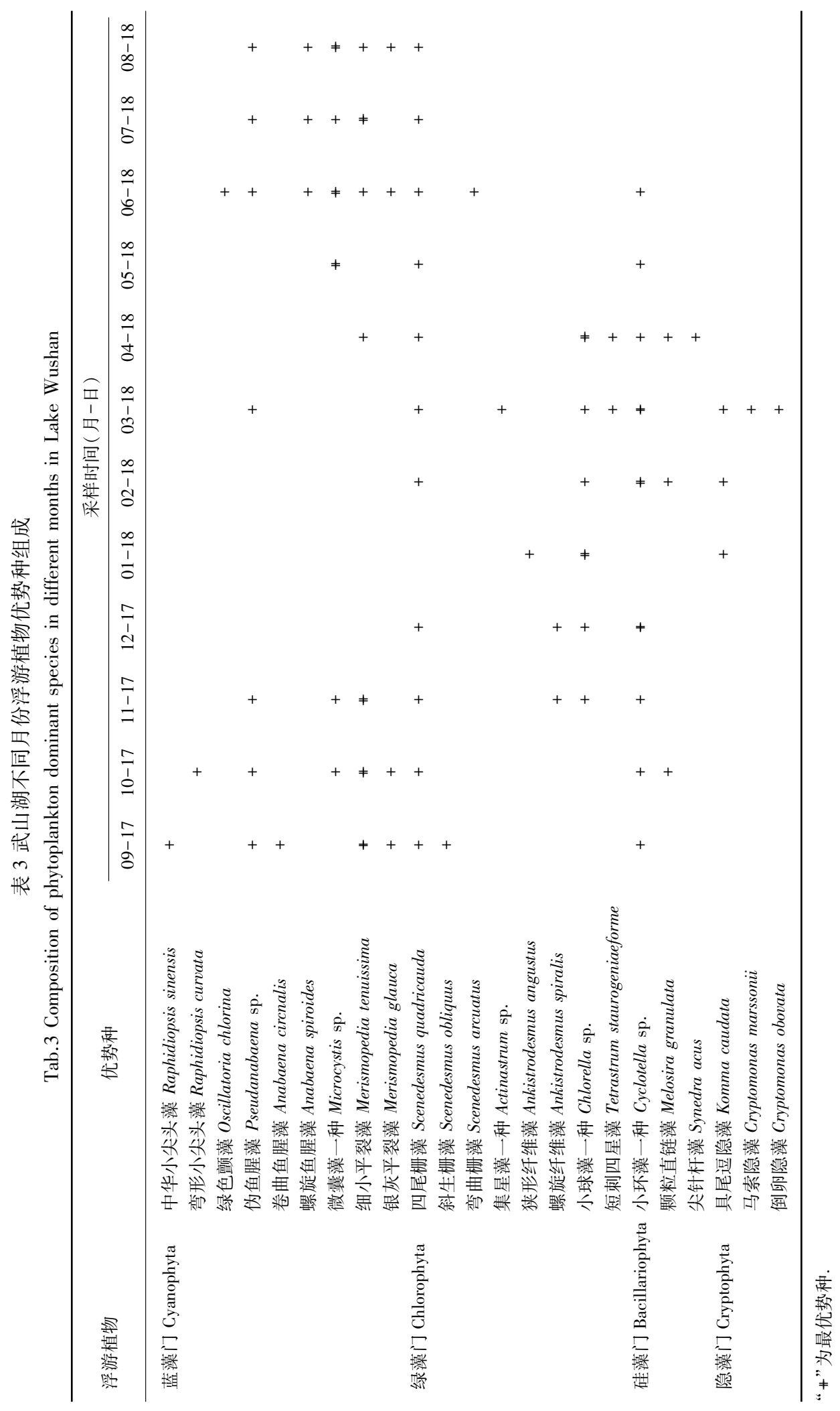



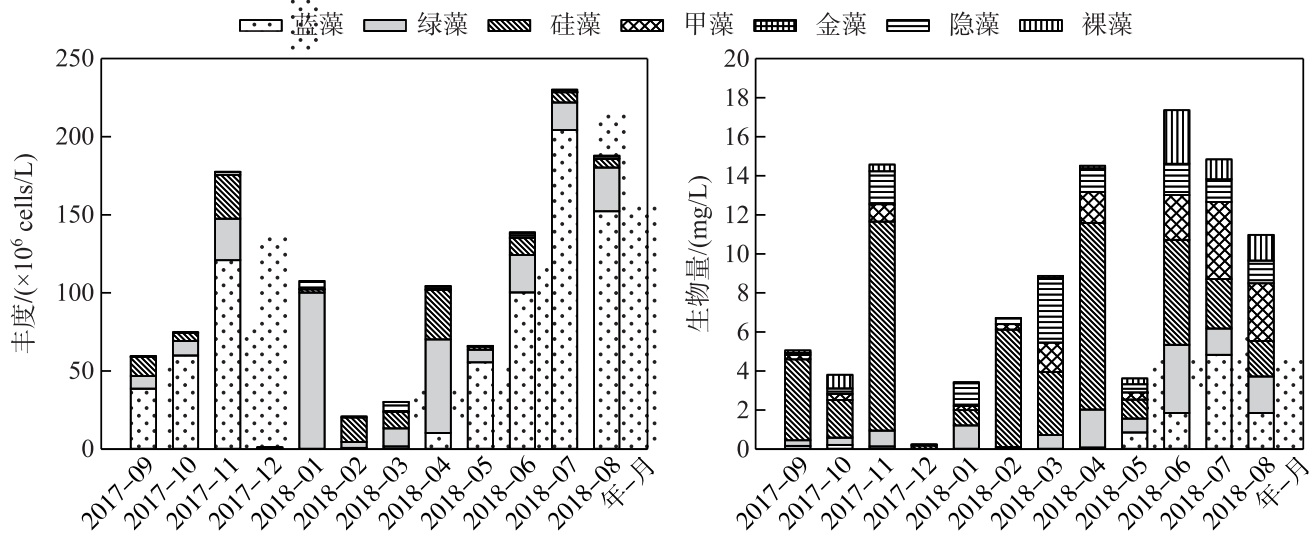

图 4 武山湖浮游植物丰度和生物量变化

Fig.4 Variations of phytoplankton abundance and biomass in Lake Wushan

表 4 武山湖浮游植物丰度、生物量与环境因子相关性分析 $(n=84)$

Tab.4 Correlation analysis between phytoplankton abundance, biomass and environmental factors in Lake Wushan $(n=84)$

\begin{tabular}{llllllll}
\hline 相关系数 & $\ln \mathrm{TN}$ & $\ln \mathrm{TP}$ & $\ln \mathrm{WT}$ & $\ln \mathrm{DO}$ & $\ln \mathrm{pH}$ & $\ln \mathrm{SD}$ & $\ln T L I$ \\
\hline $\ln ($ 浮游植物总丰度 $)$ & -0.235 & $0.694^{*}$ & $0.619^{*}$ & 0.209 & $0.757^{* *}$ & $-0.765^{* *}$ & $0.770^{* *}$ \\
$\ln ($ 浮游植物总生物量 $)$ & -0.221 & $0.669^{*}$ & $0.703^{*}$ & 0.314 & $0.869^{* *}$ & $-0.842^{* *}$ & $0.831^{* *}$ \\
$\ln ($ 蓝藻门丰度 $)$ & -0.140 & $0.787^{*}$ & 0.500 & $-0.733^{*}$ & 0.108 & -0.604 & $0.848^{* *}$ \\
$\ln ($ 绿藻门丰度 $)$ & -0.130 & 0.368 & 0.280 & 0.528 & $0.741^{* *}$ & -0.540 & 0.480 \\
$\ln ($ 硅藻门丰度 $)$ & -0.335 & 0.440 & 0.534 & 0.307 & $0.740^{* *}$ & $-0.799^{* *}$ & $0.735^{* *}$ \\
$\ln ($ 蓝藻门生物量 $)$ & -0.051 & $0.889^{* *}$ & $0.836^{* *}$ & -0.648 & 0.247 & -0.561 & $0.724^{*}$ \\
$\ln ($ 绿藻门生物量 $)$ & -0.240 & $0.592^{*}$ & $0.590^{*}$ & 0.372 & $0.825^{* *}$ & $-0.647^{*}$ & $0.629^{*}$ \\
$\ln$ (硅藻门生物量) & -0.299 & 0.459 & 0.563 & 0.274 & $0.730^{* *}$ & $-0.826^{* *}$ & $0.752^{* *}$ \\
\hline
\end{tabular}

* 表示在 0.05 水平 (双侧) 上显著相关, ** 表示在 0.01 水平 (双侧) 上显著相关; $\ln (X)$ 表示对 $X$ 取自然对数, 表中数据为 相关系数.

通过圥余分析 (RDA) 对浮游植物各优势属的丰度和生物量与环境因子之间的关系进行分析. 基于丰度 数据, 主成分轴 1 和轴 2 特征值分别是 0.361 和 0.095 , 即前两个轴共解释了 $45.6 \%$ 的浮游植物各优势属的丰 度变化 (图 5a). 主成分轴 1 和轴 2 的物种与环境因子相关性分别为 $86.6 \%$ 和 $74.9 \%$, 两轴累计百分比变化 率为 $88.4 \%$, 表明前两个轴的物种与环境因子相关性高. RDA 蒙特卡罗前向选择检验表明, TP 浓度和 WT 对浮游植物丰度变化影响最大, 这两个变量共解释了 $36.0 \%$ ( 图 5a). TP 和 WT 与蓝藻门各优势属 (Z1 Z6) 丰度、绿藻门 Z9、Z10 和硅藻门 Z13、Z14 呈正相关; 而 TN 浓度与蓝藻门所有优势属丰度均呈负相关. 透明度 与各优势属丰度均呈负相关. TN、TP、pH、WT、DO 和 SD 与轴 1 相关性系数分别为 $-0.33 、 0.81 、 0.38 、 0.76$ 、 -0.39 和 -0.53 , 而与轴 2 的相关性系数分别为 $0.08 、-0.07 、-0.53 、-0.04 、-0.49$ 和 0.39 .

基于生物量数据,主成分轴 1 和轴 2 特征值分别是 0.346 和 0.114 ,即前两个轴共解释了 $46.0 \%$ 的浮游植 物各优势属的生物量变化(图 5b). 主成分轴 1 和轴 2 的物种与环境因子相关性分别为 $91.4 \%$ 和 $77.7 \%$,两 轴累计百分比变化率为 $88.4 \%$, 表明前两个轴的物种与环境因子相关性高. RDA 蒙特卡罗检验前向选择检 验表明, WT 和 TP 浓度对浮游植物生物量变化影响最大, 这两个变量共解释了 $36.0 \%$ ( 图 5b). WT、TP 和 $\mathrm{pH}$ 与蓝藻门各优势属 (Z1 Z6) 生物量呈正相关, 与绿藻门 Z9、Z10、Z11 和硅藻门 Z13、Z14 呈正相关; 而 TN 浓 度与蓝藻门所有优势属生物量均呈负相关. 透明度与各优势属均呈负相关. 浮游植物各优势属丰度和生物 量与环境因子的相互关系分析结果相似. TN、TP、pH、WT、DO 和 SD 与轴 1 相关性系数分别为 $0.33 、-0.77$ 、 
$-0.62 、-0.87 、 0.12$ 和 0.69 , 而与轴 2 的相关性系数分别为 $-0.02 、 0.16 、-0.47 、 0.12 、-0.70$ 和 0.27 .

从 RDA 三元图 (图 5) 可以看出浮游植物样方四季分布明显, 夏季和冬季样方分布轴 2 两侧, 其中夏季 样方更集中, 而冬季样方分布在一、四象限 (丰度) 或二、三象限. 秋季和春季的样方多分布在轴 2 附近. 蓝藻 门夏季样方的多度值靠近物种箭头的延长线上, 表明其多度值在夏季高, 而绿藻门、硅藻门和隐藻门在 10 月和 11 月以及 4 月的样方多度值较其他月份高.
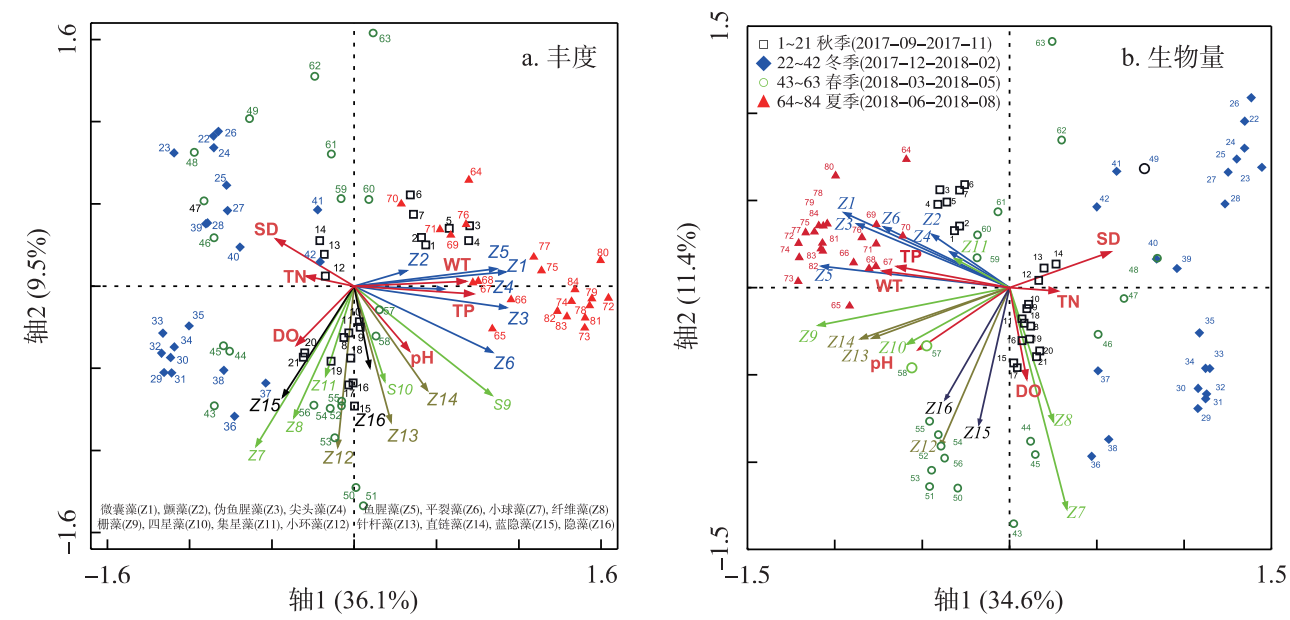

图 5 武山湖浮游植物、环境变量和采样点的圥余分析 (RDA) 三元图

Fig.5 Redundancy analysis ( RDA) triplot ( phytoplankton, environmental variables and sampling sites) in Lake Wushan

\section{3 讨论}

藻类大量增长特别是蓝藻水华的暴发以及死亡, 会严重影响湖泊水质和生态系统的健康, 因此成为湖 泊治理的一个重要问题. 根据相关湖泊富营养评价标准, 尽管武山湖各采样点由于距离人湖河口不同导致 营养盐指标存在差异(图 2), 但从整体上来讲, 武山湖 TN $(1.34 \sim 3.14 \mathrm{mg} / \mathrm{L}$ )、TP $(0.17 \sim 1.05 \mathrm{mg} / \mathrm{L}) 、 \mathrm{Chl} . a$ 浓度 (峰值达 $125.08 \mu \mathrm{g} / \mathrm{L}$ ) 以及藻类丰度和生物量均可指示武山湖水体处于富营养化水平 ${ }^{[17]}$, 具有藻类大 量生长的营养条件, 再加上武山湖藻类优势种主要是蓝藻和绿藻, 藻类水华尤其是蓝藻水华发生的风险高. 本次调查中 12 次采样共鉴定出 23 种优势种, 其中蓝藻门占 $39.1 \%$ 、绿藻门占 $34.9 \%$, 夏季和秋季蓝藻门优 势种最多且优势度高, 冬季和春季绿藻门和硅藻门优势种多且优势度高. 在长江中下游类似富营养水平湖 泊中, 浮游植物通常都是以绿藻和蓝藻为主. 如长江中游的长湖 ${ }^{[18]}$ 、沙湖 $^{[19]}$ 、太平湖 ${ }^{[20]}$ 、果湖 $^{[21]}$ 、青山湖 $^{[22]}$ 以及下游的太湖梅梁湾 ${ }^{[23]}$ 、滆湖 ${ }^{[24]}$ 、淀山湖 ${ }^{[25]}$ 等湖泊, 常见的优势种有微囊藻、平裂藻、小球藻、栅藻等属 的种类, 其中蓝藻主要以群体性如微囊藻、鱼腥藻等占优势, 绿藻以栅藻等为主. 与上述这些湖泊相比, 武山 湖的氮、磷水平接近甚至略高, 其藻优势种及其季节变化与这些已研究报道的湖泊呈现类似特征. 然而, 从 丰度和生物量上来看, 武山湖浮游植物丰度在 $0.41 \times 10^{6} \sim 341.46 \times 10^{6} \mathrm{cells} / \mathrm{L}$ 之间, 峰值已经远高于太平湖 $\left(6.41 \times 10^{6} \text { cells } / \mathrm{L}\right)^{[20]}$ 、淀山湖 $\left(102 \times 10^{6} \text { cells } / \mathrm{L}\right)^{[25]}$ 浮游植物丰度峰值, 但小于青山湖 $\left(726 \times 10^{6} \text { cells } / \mathrm{L}\right)^{[22]}$ 和巢湖浮游植物丰度峰值 $\left(\text { 约 } 800 \times 10^{6} \mathrm{cells} / \mathrm{L}\right)^{[21]}$. 根据报道, 淀山湖、青山湖和巢湖均曾暴发成片藻类水 华,而武山湖目前 Chl. $a$ 浓度、丰度等均达到很高水平,但是在监测过程中,没有成片藻类聚集现象发生.

$\mathrm{RDA}$ 分析表明武山湖的 WT、TP 和 $\mathrm{pH}$ 是影响浮游植物增长及其种群分布的关键理化因子. 温度是影 响浮游植物的最重要理化因子之一, 温度不仅会影响浮游植物生长率, 而且会影响其群落结构变化 ${ }^{[26-28]}$. 在 武山湖, 水温是影响浮游植物季节变化的最重要环境因子, 与蓝藻、绿藻和硅藻均呈正相关, 并可独立解释 $28 \%$ 的浮游植物丰度和 $32 \%$ 的生物量变化. 武山湖夏季 (6-8 月) 浮游植物以蓝藻门微囊藻、细小平裂藻等 蓝藻为主, 高温和高磷浓度可能是导致其大量生长的主要原因, 大量研究也表明夏季藻类种群分布的主要 
影响因子是温度和磷 ${ }^{[21,23]}$. 聚类分析 (图 3a) 和 RDA 分析 (图 5) 可清唽表明, 武山湖浮游植物群落结构的变 化具有明显的季节特征, 当水温升高时绿藻和蓝藻的丰度和生物量均显著增高, 原因为蓝藻、绿藻喜高温, 其主要出现在温度较高的季节 ${ }^{[29-32]}$. 一般来说, 蓝藻、绿藻的生长最适温度为 $25 \sim 35^{\circ} \mathrm{C}^{[33]}, 15^{\circ} \mathrm{C}$ 以下其生长 受到限制 ${ }^{[34]}$. 本研究中蓝藻的生长与上述研究结果一致, 但绿藻部分优势种的生长与其不一致, 如绿藻门 小球藻一种曾在 1 月份成为优势种, 可能受到冬季捕捞等因素的影响. 小球藻在温度较低的季节易成为优 势种 ${ }^{[1,23]}$, 武山湖冬季捕捞后浮游植物面临的牧食压力大大降低, 而小球藻生长繁殖速度又快, 这可能是其 在 1 月份成为最优势种的原因. 武山湖冬季和春季隐藻、硅藻占优势与多数研究结果一致 ${ }^{[34]}$.

而对于氮磷来说, 其往往是浮游植物生长和分布的限制因子 ${ }^{[35]}$. 本研究中磷浓度的增加有利于蓝藻、 绿藻和硅藻的生长, 其对蓝藻增长的影响尤为明显. 磷是浮游植物存活的必要条件, 浮游植物的物种多样 性、丰度和生物量与营养盐的组成和浓度是密不可分的, 浮游植物的增长一般与磷呈正相关 ${ }^{[35]}$. 但对于氮 来说, RDA 分析表明武山湖 $\mathrm{TN}$ 与浮游植物生长呈负相关且相关性不显著, 出现负相关的原因可能是因为武 山湖 TN 浓度因外源污染排人所出现的峰值与藻类的生长峰值季节上不同步, 同时温度升高在促进藻类生 长的同时会造成水体脱氮能力增加 ${ }^{[36]}$. 在一些研究中也发现 TN 浓度与浮游植物生长呈负相关 ${ }^{[15,37-38]}$, 水 体中氮浓度峰值一般出现在初春, 由于温度低限制了藻类生长, 使得氮浓度峰值和藻类生物量峰值产生了 季节错位. 例如, 在太湖水体中氮、磷浓度就存在类似武山湖的季节变化, 氮在春季和冬季浓度较高, 而在夏 季和秋季浓度较低; 磷浓度的季节变化与氮相反, 春季和冬季浓度较低, 而夏季和秋季相对较高 ${ }^{[39]} \cdot \mathrm{pH}$ 对浮 游植物群落也有着重要影响, 当 $\mathrm{pH}>8.0$ 时, 蓝藻往往成为主要优势种 ${ }^{[40]}$. 同时, 蓝藻可通过一系列的生理 生化反应来调节水体 $\mathrm{pH}$, 使其维持在适宜藻类生长的范围内 ${ }^{[41]}$. 藻类种群分布与水体 $\mathrm{pH}$ 值的相关性也可 能是由于不同环境条件下藻类种群的生长繁殖变化导致水体 $\mathrm{pH}$ 值变化所致 ${ }^{[42]}$.

此外, 在武山湖, 浮游植物群落结构及现存量对以鲢、鳙尤其是鳙为主的鱼类结构的响应值得讨论. 采 样期间武山湖放养的鱼类主要是鲢 (约 $21 \%$ )、鲔(约 70\%), 其中鲢现存量约为 $12.6 \mathrm{~g} / \mathrm{m}^{3}$ 、鳙约为 $33.8 \mathrm{~g} /$ $\mathrm{m}^{3}$, 二者比值约 $3: 7$. 一般认为鲢主要摄食浮游植物, 而鳙主要摄食浮游动物 ${ }^{[43]}$; 但刘恩生等研究发现在以 水华蓝藻为主要初级生产力的富营养化湖泊中, 鲢、鳙的食性会根据环境的变化而发生改变, 它们均以微囊 藻为主要食物 ${ }^{[4]}$; 王媛等基于稳定同位素技术也证实鲢、鳙的主要食物来源为悬浮颗粒有机物,而悬浮颗粒 有机物的主要来源为水华蓝藻 ${ }^{[45]}$. 本研究同期采集的鱼类同位素测定结果也显示鲢和鲔的 $\delta^{15} \mathrm{~N}$ 值均接近 $13.0 \%{ }^{[46]}$, 无显著区别, 表明武山湖鲢、鳙鱼食性可能类似. 在调查中发现, 武山湖 2018 年夏季浮游植物最 优势种为微囊藻, 丰度也很高, 但是从 2017-2018 年周年监测期间并没有出现大规模的水华及藻类聚集在 水面的现象. 李林春对南湾水库投放鲢、鳙研究表明, 当鲢与鳙的比值在 $4: 6$ 的情况下, 能显著降低浮游植 物的数量和生物量, 同时也大大降低了蓝藻在藻类群落中所占的比例及其生物量, 有效地避免了南湾水库 蓝藻水华的暴发 ${ }^{[5]}$. 在 1998 和 1999 年, 千岛湖连续暴发了 2 次大面积的蓝藻水华, 据研究, 鲢、鳙生物量的 减少可能是其主要原因 ${ }^{[47]}$. 冯超群等于 2016 年 7 月, 在太湖三国城水域设置孔径为 $1.5 \mathrm{~cm}$ 的大型尼龙网围 栏, 面积约 $866.7 \mathrm{hm}^{2}$, 鲢、鳙比例为 $1: 1$, 初始鲢、鳙约 $2.9 \mathrm{~g} /$ 尾, 生物量约 $3.27 \mathrm{~g} / \mathrm{m}^{3}$, 捕捞时围网内鲢、鳙生 物量约 $82.85 \mathrm{~g} / \mathrm{m}^{3}$, 结果表明单纯放养鲢、鲔适合控制蓝藻水华而非藻类总量, 试验期间围栏内大型藻类如 束丝藻、假鱼腥藻属等生物量显著下降, 到试验结束时几乎消失 ${ }^{[48]}$. 刘其根等综合分析众多鲢、鲜控藻研究 结果, 认为无论是基于稳定性同位素或 PCR-DGGE 食性分析, 还是通过合理的围隔实验, 以及大量的养殖实 践, 均证实了鲢、鳙是能够控制蓝藻过度生长, 但其应用效果受多种因素影响 ${ }^{[7]}$. 因此, 尽管对鲢、鳙放养是 否能把浮游植物的数量和生物量控制在较低水平目前还存在很多争议, 但是对当鲢、鳙养殖密度达到一定 程度时可有效控制富营养水体中蓝藻的过度生长, 且鲢、鳙的滤食作用会阻止藻类在水面聚集成片这一观 点得到较多研究验证.

\section{4 结论}

1) 综合理化因子、营养状态指数及浮游植物丰度、生物量等指标, 采样期间武山湖水质营养程度处于中 度一重度富营养水平.

2) 武山湖夏季和秋季蓝藻门优势种最多且优势度高, 冬季和春季绿藻门和硅藻门优势种多且优势度 
高, 每月优势度最大的种类主要有蓝藻门的微囊藻一种和细小平裂藻、绿藻门的小球藻一种与硅藻门的小 环藻一种, 表明武山湖浮游植物优势种主要是小型藻类.

3 ) 武山湖浮游植物丰度和生物量在夏季均较高, 夏季发生大规模藻类水华的风险较高. RDA 和线性相 关分析结果表明影响浮游植物丰度和生物量的主要营养元素是磷, 磷浓度增加与蓝藻和绿藻的丰度和生物 量呈正相关, 表明外源磷输人和内源磷释放的控制应引起重视. 在武山湖目前外源污染量还较大的情况下, 鲢、鳙的放养对浮游植物过度生长的控制具有积极意义.

\section{5 参考文献}

[ 1 ] Li LX, Zha M. Thinking on further perfecting and upgrading drainage system in 'Sanhu' areas of Wuxue. Water Conservancy Construction and Management, 2017, 37(4): 65-77. [李龙绪, 查敏. 关于进一步完善和改造武穴市“三湖”地区 排涝系统的思考. 水利建设与管理, 2017, 37(4): 65-77.]

[ 2 ] Jian YX, Wang JB, He GQ et al. A comparative study of aquatic plant diversity of Haikou, Taibai, and Lake Wushan in Hubei Province of China. Acta Ecologica Sinica, 2000, 21(11)：1815-1824. [简永兴, 王建波, 何国庆等. 湖北省海 口湖、太白湖与武山湖水生植物多样性的比较研究. 生态学报, 2000, 21(11): 1815-1824.]

[ 3 ] Peng YH, Ni LY, Jian YX et al. A comparative study on aquatic plant diversity in six lakes of Dongting-Poyang district in China. Acta Botanica Yunnanica, 2004, 26(2) : 191-198. [彭映辉, 倪乐意, 简永兴等. 两湖平原六个湖泊水生植物 多样性的比较研究. 云南植物研究, 2004, 26(2) : 191-198.]

[ 4 ] Xie P ed. Silver carp, bighead carp and algae bloom control. Beijing: Science Press, 2003. [谢平. 鲢、鳙与藻类水华控 制. 北京: 科学出版社, 2003.]

[ 5 ] Li LC. Study of fish culture manipulation on Nanwan Reservoir eutrophication water quality. Journal of Hydroecology, 2010, 3(4) : 70-72. DOI: 10.15928/j.1674-3075.2010.04.016. [李林春. 南湾水库鲢鳙放养比例对水质调控的研 究. 水生态学杂志, $2010,3(4)$ :70-72.]

[ 6 ] Wang SB, Qu YF, Xu ZR et al. Algal bloom control in eutrophic lakes and reservoirs based on biomanipulation. Water Resources Protection, 2016, 32(5): 1-4. [王寿兵, 屈云芳, 徐紫然等. 基于生物操纵的富营养化湖库蓝藻控制实践. 水资源保护, 2016, 32(5): 1-4.]

[ 7 ] Liu QG, Zhang Z. Controlling the nuisance algae by silver and bighead carps in eutrophic lakes: disputes and consensus. $J$ Lake Sci, 2016, 28(3) : 463-475. DOI: 10.18307/2016.0301. [刘其根, 张真. 富营养化湖泊中的鲢、鳙控藻问题: 争议与共识. 湖泊科学, 2016,28 (3) : 463-475.]

[ 8 ] Ministry of Environmental Protection of the People's Republic of China, Editorial Board of Water and Wastewater Monitoring and Analysis Methods eds. Water and Wastewater Monitoring and Analysis Methods: 4th edition. Beijing: China Environmental Science Press, 2002. [ 国家环境保护总局《水和废水监测分析方法》编委会. 水和废水监测分析方法: 第 4 版. 北京: 中国环境科学出版社, 2002.]

[ 9 ] Hu HJ, Wei YX eds. Chinese freshwater algae—system, classification and ecology. Beijing: Science Press, 2006. [胡鸿 均, 魏印心. 中国淡水藻类——系统, 分类及生态. 北京: 科学出版社, 2006.]

[10] Zhang ZS, Huang XF eds. Research methods of freshwater plankton. Beijing: Science Press, 1995. [ 章宗涉, 黄祥飞. 淡 水浮游生物研究方法. 北京: 科学出版社, 1995.]

[11] Wang MC, Liu XQ. Evaluate method and classification standard on lake eutrophication. Environmental Monitoring in Chi$n a, 2002,18(5): 47-49$. [王明翠, 刘雪芹. 湖泊富营养化评价方法及分级标准. 中国环境监测, 2002, 18 (5): 47-49.]

[12] The Ministry of Water Resources of the People's Republic of China ed. China Water Resource Bulletin. Beijing: China Water \& Power Press, 2005. [中华人民共和国水利部. 中国水资源公报. 北京：中国水利水电出版社, 2005.]

[13] Mcnaughton SJ. Relationships among functional properties of Californian Grassland. Nature, 1967, 216(5111) : 168-169. DOI: $10.1038 / 216168$ b0.

[14] Fott B ed. Luo DA translated. Phycology. Shanghai: Shanghai Scientific and Technical Publishers, 1980: 422-428. [B. 福 迪 (捷克). 罗迪安译. 藻类学. 上海: 上海科学技术出版社, 1980: 422-428.]

[15] Liu LF, Zhou XH, Gao J et al. Phytoplankton community structure and trophic status evaluation in Dajiuhu wetland of Shennongjia Alpine. J Lake Sci, 2018, 30(2) : 417-430. DOI: 10. 18307/2018.0213. [刘林峰, 周先华, 高健等. 神农 架大九湖湿地浮游植物群落结构特征及营养状态评价. 湖泊科学, 2018, 30(2) : 417-430.] 
[16] Lepš J, Šmilauer P eds. Multivariate analysis of ecological data using CANOCO. London: Cambridge Univiversity Press, 2003.

[17] Liu JK ed. Advanced Hydrobiology. Beijing: Science Press, 1999: 331-333. [刘建康. 高级水生生物学. 北京: 科学出 版社, 1999: 331-333.]

[18] He YF, Li HC, Zhu YJ et al. Status and spatial-temporal variations of eutrophication in Lake Changhu, Hubei Province. $J$ Lake Sci, 2015, 27 (5) : 853-864. DOI: 10.18307/2015.0511. [何勇风, 李吴成, 朱永久等. 湖北长湖富营养化状况 及时空变化(2012-2013 年). 湖泊科学, 2015, 27(5): 853-864.]

[19] Lu L, Wu YX, Zhang WH. Distribution and succession pattern of phytoplankton communities in a small urban lake, Sand Lake in Wuhan City, China. Acta Ecologica Sinica, 2017, 37(18) : 5993-6004. DOI: 10.5846/stxb201606211215. [鲁 蕾, 吴亦潇, 张维吴. 城市小型湖泊浮游植物群落结构特征及演替规律一以武汉沙湖为例. 生态学报, 2017,37 (18) : 5993-6004.]

[20] Xiong L, Liu DY, Wang JL. Phytoplankton community structure in Lake Taiping of Anhui Province. J Lake Sci, 2016, 28 (5) : 1066-1077. DOI: 10.18307/2016.0517. [ 熊莲, 刘冬燕, 王俊莉等. 安徽太平湖浮游植物群落结构. 湖泊科 学, 2016, 28(5): 1066-1077.]

[21] Yang LB, Han XY, Sun P et al. Canonical correspondence analysis of algae community and its environmental factors in the Lake Chaohu, China. Journal of Agro-Environment Science, 2011, 30(5)：952-958. [杨丽标, 韩小勇, 孙璞等. 巢湖 藻类组成与环境因子典范对应分析. 农业环境科学学报, 2011, 30(5) : 952-958.]

[22] Zhang YG, Xie JL, Li SC. The analysis on the structure of phytoplankton community in Qingshan Lake of Nanchang City. Journal of Jiangxi Normal University: Natural Science, 2018, 42(5): 64-70. [张毅鸽, 谢金林, 李守淳. 南昌市青山 湖浮游植物群落结构的分析. 江西师范大学学报: 自然科学版, 2018, 42(5): 64-70.]

[23] Cai LL, Zhu GW, Zhu MY et al. Succession of phytoplankton structure and its relationship with algae bloom in littoral zone of Meiliang Bay, Taihu Lake. Ecological Science, 2012, 31(4): 345-351. [蔡琳琳, 朱广伟, 朱梦圆等. 太湖梅梁湾湖 岸带浮游植物群落演替及其与水华形成的关系. 生态科学, 2012, 31(4) : 345-351.]

[24] Gao Y, Pan JZ, Li Y et al. Spatial-temporal distribution of phytoplankton and environmental factors in the north part of Lake Gehu(Jiangsu) after muti-treatment. J Lake Sci, 2015, 27(4) : 649-656. DOI: 10.18307/2015.0413. [高亚, 潘继征, 李 勇等. 江苏滆湖北部区整治后浮游植物时空分布及环境因子变化规律. 湖泊科学, 2015, 27(4) : 649-656.]

[25] Wang LQ, Xu L, Lu ZY et al. Dynamic of phytoplankton abundance and the relationship with environmental factors in dianshan lake, Shanghai. Environmental Science, 2011, 32(10) : 2868-2874. DOI: 10.13227/j.hjkx.2011.10.007. [王丽 卿, 许莉, 卢子园等. 淀山湖浮游植物数量消长及其与环境因子的关系. 环境科学, $2011,32(10): 2868-2874$.]

[26] Rhee GY, Gotham IJ. The effect of environmental factors on phytoplankton growth: temperature and the interactions of temperature with nutrient limitation. Limnology and Oceanography, 1981, 26(4) : 635-648. DOI: 10.4319/lo. 1981.26. 4.0635 .

[27] Elliott JA, Jones ID, Thackeray SJ. Testing the sensitivity of phytoplankton communities to changes in water temperature and nutrient load, in a temperate lake. Hydrobiologia, 2006, 559(1) : 401-411. DOI: 10.1007/s10750-005-1233-y.

[28] Edwards KF, Thomas MK, Klausmeier CA et al. Phytoplankton growth and the interaction of light and temperature: a synthesis at the species and community level. Limnology and Oceanography, 2016, 61 (4) : 1232-1244. DOI: 10.1002/ lno. 10282 .

[29] Dong ZW, Zhao XY, Chen LH et al. Phytoplankton community changes during wetland restoration in Jinghe Estuary, Lake Ebinur, Xinjiang. J Lake Sci, 2011, 23(3) : 395-400. DOI: 10.18307/2011.0312. [董正武, 赵晓英, 陈丽华等. 新疆 艾比湖精河人湖口退化湿地恢复过程中浮游植物群落的变化. 湖泊科学, 2011, 23(3): 395-400.]

[30] Chen LJ, Wu ZC, Hu ZJ et al. Phytoplankton community structure in Mingzhu Lake of Chongming Island, Shanghai. Chinese Journal of Applied Ecology, 2011, 22(6): 1599-1605. [陈立婧, 吴竹臣, 胡忠军等. 上海崇明岛明珠湖浮游植 物群落结构. 应用生态学报, $2011,22(6): 1599-1605$.

[31] Chen Q, Zhang C, Recknagel F et al. Adaptation and multiple parameter optimization of the simulation model SALMO as prerequisite for scenario analysis on a shallow eutrophic Lake. Ecological Modelling, 2014, 273(7) : 109-116. DOI: 10. 1016/j.ecolmodel.2013.11.006.

[32] Wu AQ, Guo N, Qin XB. Seasonal variation of phytoplankton functional groups and their relationship with environmental factors in a typical cold regions wetland. Acta Scientiae Circumstantiate, 2015, 35(5) : 1341-1349. DOI: 10.13671/j. hjkxxb.2014.0729. [武安泉, 郭宁, 覃雪波. 寒区典型湿地浮游植物功能群季节变化及其与环境因子关系. 环境科 
学学报, 2015, 35(5): 1341-1349.]

[33] Nalewajko C, Murphy TP. Effects of temperature, and availability of nitrogen and phosphorus on the abundance of Anabae$n a$ and Microcystis in Lake Biwa, Japan: an experimental approach. Limnology, 2001, 2 (1): 45-48. DOI: 10. $1007 /$ s102010170015.

[34] Robarts RD, Zohary T. Temperature effects on photosynthetic capacity, respiration, and growth rates of bloom-forming cyanobacteria. New Zealand Journal of Marine and Freshwater Research, 1987, 21(3) : 391-399. DOI : 10.1080/00288330. 1987.9516235 .

[35] Søndergaard M, Lauridsen TL, Johansson LS et al. Nitrogen or phosphorus limitation in lakes and its impact on phytoplankton biomass and submerged macrophyte cover. Hydrobiologia, 2017, 795(1) : 35-48.

[36] Zhu GW, Qin BQ, Zhang JL et al. Variation and driving factors of nutrients and chlorophyll-a concentrations in northern region of Lake Taihu, China, 2005-2017. J Lake Sci, 2018, 30(2) : 279-295. DOI: 10.18307/2018.0201. [朱广伟, 秦伯强, 张运林等. 2005-2017 年北部太湖水体叶绿素 a 和营养盐变化及影响因素. 湖泊科学, 2018, 30(2) : 279-295.]

[37] Bi JB, Zheng J, Shen YF et al. Spatial-temporal characteristics of chlorophyll-a concentration and its relationship with environmental factors in the inlets of South Taihu Lake. Journal of Hydroecology, 2012, 33(6) : 7-13. [毕京博, 郑俊, 沈 玉凤等. 南太湖人湖口叶绿素 $a$ 时空变化及其与环境因子的关系. 水生态学杂志, 2012, 33(6) : 7-13.]

[38 ] Wang YP, You WH, Hu XQ et al. Seasonal dynamics of Cyanophyta and related affecting factors in Dianshan Lake. Chinese Journal of Ecology, 2010, 29(12) : 2477-2485. DOI: 10.13292/j.1000 -4890.2010.0371. [汪益嫔, 由文辉, 胡雪 芹等. 淀山湖蓝藻季节动态及其影响因子. 生态学杂志, 2010, 29(12) : 2477-2485.]

[39] Xu H, Paerl HW, Qin B et al. Nitrogen and phosphorus inputs control phytoplankton growth in eutrophic Lake Taihu, China. Limnology and Oceanography, 2010, 55(1) : 420-432. DOI: 10.4319/lo.2010.55.1.0420.

[40] Zhang Y, Ma XF, Guo FF et al. Community structures of phytoplankton and their relationships with environmental factors in the Jinshahe Reservoir, Hubei Province. J Lake Sci, 2015, 27(5) : 902-910. DOI: 10.18307/2015.0517. [张云, 马 徐发, 郭飞飞等. 湖北金沙河水库浮游植物群落结构及其与水环境因子的关系. 湖泊科学, 2015, 27 (5) : 902-910.]

[41] Xu H, Qin BQ, Zhu GW. Nutrient limitation of cyanobacterial growth in different regions of LakeTaihu in summer. China Environmental Science, 2012, 32(12) : 2230-2236. [许海, 秦伯强, 朱广伟. 太湖不同湖区夏季蓝藻生长的营养盐 限制研究. 中国环境科学, 2012, 32(12): 2230-2236.]

[42] Yang LB, Han XY, Sun P et al. Canonical correspondence analysis of algae community and its environmental factors in the Lake Chaohu. Journal of Agro-Environment Science, 2011, 30(5): 952-958. [杨丽标, 韩小勇, 孙璞等. 巢湖藻类组成 与环境因子典范对应关系. 农业环境科学学报, 2011, 30(5): 952-958.]

[43] Ni DS, Jiang XZ. Food problems for bighead and silver carp. Current Zoology, 1954, 6( 1) : 59-71. DOI: ir.ihb.ac.cn/ handle/152342/7412. [倪達書, 蒋隻治. 花鲢和白鲢的食料问题. 动物学报, 1954, 6(1): 59-71.]

[44] Liu ES, Bao CH, Cao P et al. Analysis of food composition and the changes of fish catch of silver carp and bighead carp. Reservoir Fisheries, 2007, 27 (4) : 72-74. [刘恩生, 鲍传和, 曹萍等. 太湖鲢、鳙的食物组成及渔获量变化原因分析. 水利渔业, 2007, 27(4): 72-74.]

[45] Wang Y, Xu DP, Wang XL et al. Feeding differences of silver carp and bighead carp in the northern part of Taihu Lake: based on stable carbon and nitrogen isotope analysis. Journal of Dalian Ocean University, 2017, 32(5) : 598-602. [王媛, 徐东坡, 王小林等. 基于碳氮稳定同位素技术探究太湖北部湖区鲢、鳙食性差异. 大连海洋大学学报, 2017, 32 (5) : 598-602.]

[46] Zhang JM. Study on plankton community structure and food web structure in Lake Wushan of Hubei Province[ Dissertation]. Wuhan: Hubei University of Technology, 2019. [张佳敏. 湖北武山湖浮游生物群落结构及食物网结构研究 [学位论文]. 武汉: 湖北工业大学, 2019.]

[47] Liu QG, Chen LQ, Chen Y. Correlation between biomass reduction of silver carp and bighead carp and the occurrence of algal blooms in Lake Qiandaohu. Transactions of Oceanology and Limnology, 2007, (1) : 117-124. [刘其根, 陈立侨, 陈勇等. 千岛湖水华发生与主要环境因子的相关性分析. 海洋湖沼通报, 2007, (1): 117-124.]

[48] Feng CQ, Xu DP, Chen YJ et al. Effects of silver carp and bighead carp on phytoplankton community in the waters of the Three Kingdoms City, Taihu Lake. Journal of Dalian Ocean University, 2018, 33(5)：118-125. [冯超群, 徐东坡, 陈 永进等. 鲢鳙放流对太湖三国城水域浮游植物的影响. 大连海洋大学学报, 2018, 33(5): 118-125.] 